\begin{tabular}{|l|l|l||}
\hline \multicolumn{2}{|c|}{ PublisherInfo } \\
\hline \hline PublisherName & $:$ & BioMed Central \\
\hline \hline PublisherLocation & $:$ & London \\
\hline \hline PublisherImprintName & $:$ & BioMed Central \\
\hline \hline
\end{tabular}

\title{
Genes that provide tumors with blood
}

\begin{tabular}{|l|l|l||}
\hline \multicolumn{2}{|c|}{ ArticleInfo } \\
\hline \hline ArticleID & $:$ & 3751 \\
\hline \hline ArticleDOI & $:$ & $10.1186 /$ gb-spotlight-20000824-01 \\
\hline \hline ArticleCitationID & $:$ & spotlight-20000824-01 \\
\hline \hline ArticleSequenceNumber & $:$ & 188 \\
\hline \hline ArticleCategory & $:$ & Research news \\
\hline \hline ArticleFirstPage & $:$ & 1 \\
\hline \hline ArticleLastPage & $:$ & 2 \\
\hline \hline & $:$ & RegistrationDate : 2000-08-24 \\
ArticleHistory & $:$ & OnlineDate $\quad$ 2000-08-24 \\
\hline \hline ArticleCopyright & $:$ & BioMed Central Ltd2000 \\
\hline \hline ArticleGrants & $:$ & \\
\hline \hline ArticleContext & $:$ & 130591111 \\
\hline \hline
\end{tabular}


William Wells

Email: wells@biotext.com

In the 18 August Science St. Croix et al. present an expression analysis of endothelial cells from blood vessels of normal and malignant colorectal tissue (Science 2000, 289:1197-1202). After developing a method for purifying these scarce cells, they use serial analysis of gene expression (SAGE) to identify a host of new pan-endothelial markers that are not expressed in other tissues. Additionally, 46 SAGE tags are elevated tenfold or more specifically in tumor endothelium, and at least 7 of these tumor endothelial markers (TEMs) are associated with genes that affect extracellular matrix formation or remodeling. Many of the TEMs are not expressed in normal resting endothelium, but they are found in the endothelium of other cancers, and, for the most part, in normal growing endothelium. This suggests that cancer angiogenesis is very similar to normal blood vessel growth, but the few differences may be critical for developing anti-cancer therapies.

\section{References}

1. Science magazine, [http://www.sciencemag.org/]

2. Serial analysis of gene expression. 